Mersin Photogrammetry Journal

https://dergipark.org.tr/en/pub/mephoj

e-ISSN 2687-654X

\title{
3D model of Üçayak Ruins obtained from point clouds
}

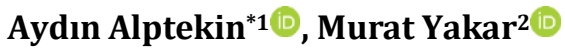 \\ 1Mersin University, Engineering Faculty, Geological Engineering Department, Mersin, Turkey \\ 2Mersin University, Engineering Faculty, Geomatics Engineering Department, Mersin, Turkey
}

\author{
Keywords \\ Cultural heritage \\ UAV \\ 3D Model \\ Photogrammetry \\ Circular mission plan
}

\begin{abstract}
Historical artifacts are in danger all over the world as they are being damaged continuously. In order to transfer them to future generations and restore them, we need to create digital products of them. The developments in remote sensing allow us to model objects in computer environment. In this study, a cultural heritage located in Mersin was modelled in 3D using an unmanned aerial vehicle (UAV). Circular mission plan in the mobile phone application was preferred. Overlapping pictures were aligned. Digital surface model, orthophoto and 3D model of Ucayak Ruins have been created. Aerial photogrammetry allows us to create digital products in a short time. The obtained model will be used in tourism advertisements.
\end{abstract}

\section{Introduction}

Turkey has hosted many civilizations throughout history. Turkey has been preferred for settlement because it is surrounded by the sea on three sides, is located on migration routes and has fertile agricultural lands. Assyrians, Byzantine, Seljuk and Ottoman Empires have lived in this territory. These civilizations have left us cultural legacies. As a result, Turkey has a deep history of geoarchaeological sites.

Mersin City, located in the southern parts of Turkey, has a great potential for archeological studies (Alptekin and Yakar 2021). There are many archaeological study areas such as Kizkalesi, Olba Ancient City, Anemurium, Heaven Hell Potholes and Uzuncaburç. They are being negatively affected from natural and anthropogenic effects.

Geopark turizm has been gaining importance since last decade. Geoparks occur with the process of million years. Mut Miocene Basin is one of the candidates Geopark sites in Turkey. Moreover, it has canyon, valley, and waterfall in it. Geoparks are open air laboratories to describe geological events.

Agriculture and tourism are the main incomes of Mersin. Geo-tourism is important for rural development of Turkey (Kocalar, 2020; Varol et al. 2021). However, Mersin is experiencing a lack of publicity.

Historical artifacts are important sources that enable us to reach the life information of the past (Yakar et al. 2005; Yakar et al. 2010). However, they are being damaged due to the unconscious behaviors of people, treasure hunters, natural disasters and climate changes (Ulvi and Yakar, 2010). We need to document our cultural heritage in the computer environment, in order to pass it on to future generations, use it in tourism and restore it in the future (Yakar et al. 2016).

Terrestrial laser scanner (TLS) and unmanned aerial vehicle (UAV) have been used to model the archeological sites in 3D since last decade. Alptekin et al. 2019 have used TLS to model the mausoleum in Kanlıdivane.

In this study, Üçayaklı ruins located in Erdemli province of Mersin city was modeled using a UAV. Üçayaklı ruins, also called villa rustika, was the residence of the great landowners during the Roman and Byzantine periods. The walls of the building, which has been well preserved until today, are intact. However, the ceiling and floor, which was made of wooden, were demolished (Çalışkan et al.2009). The 
second floor has large windows and consoles that prove the presence of a balcony, while the first floor has small windows (Fig.1).

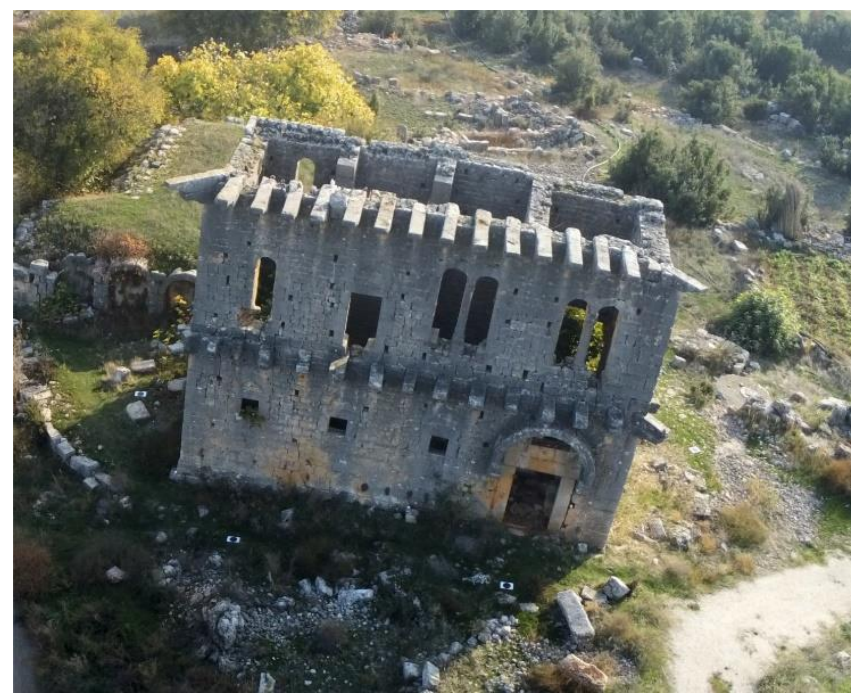

Figure 1. Ucayak ruins

\section{Study area}

Mersin is located between Mediterrenean Sea and Taurus Mountains. The study area is located in Erdemli Disrict, Mersin Province (Figure 2). Ucayak Ruins is between Küstülü and Hüsametli villages. Total distance to Mersin city center is $65 \mathrm{~km}$.

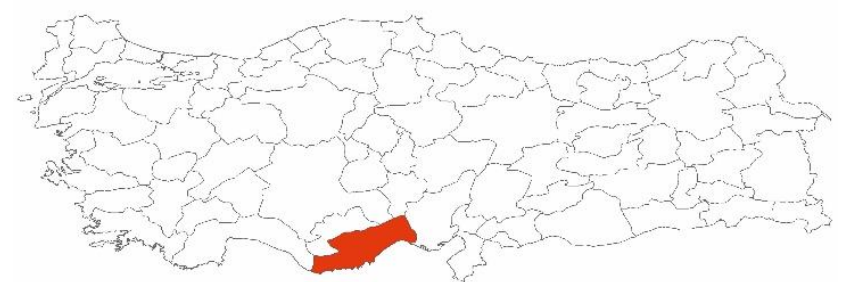

Figure 2. Location map

\section{Methods}

UAV has been frequently used in engineering projects since last decade. UAV has been used in agriculture (Bendig et al. 2014; Şenol et al. 2021), culture heritage modelling (Şasi and Yakar, 2018; Ulvi et al. 2019; Sarı et al. 2020), mapping landslide area (AlRawabdeh et al. 2017; road extraction (Yiğit and Uysal, 2021), shoreline change detection (Unel et al. 2019), pond volume measurement (Alptekin and Yakar 2020).

Obtaining accurate and complete data will increase the accuracy of the documentation work (Hamal et al. 2020). Visual and scientific applications of 3D modelling have a great role in documentation of cultural heritage (Yllmaz et al. 2008). Terrestrial photogrammetry is not able to take pictures from the roof of the structure. Aerial photogrammetry will solve this problem. Therefore, aerial photogrammetry will be selected in building modelling projects.

There are many softwares such as Agisoft, ContextCapture and Photomodeller that can model the object in 3D. Kabadayl et al. 2020 have discussed the advantages and disadvantages of these softwares.
In this study, Anafi Parrot (Figure 3) has been used to take pictures of cultural heritage. Technical properties of Anafi Parrot is given in Table 1.

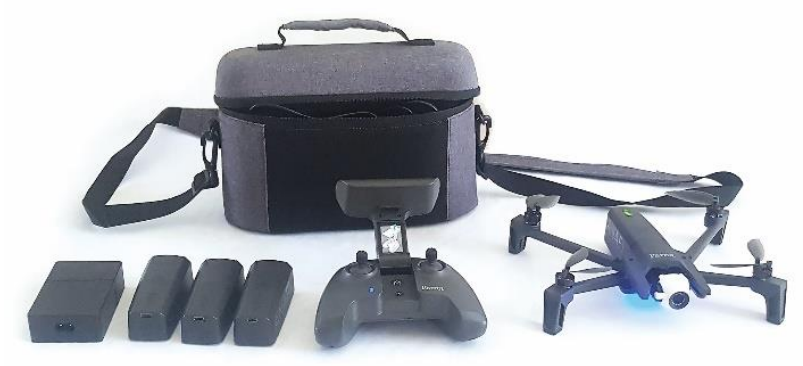

Figure 3. Anafi Parrot

Table 1. Technical properties of Anafi Parrot

\begin{tabular}{ll}
\hline Property & Value \\
\hline Drone weight & $320 \mathrm{~g}$ \\
Controller weight & $386 \mathrm{~g}$ \\
Battery weight & $126 \mathrm{~g}$ \\
Max. flight time & $25 \mathrm{~min}$ \\
Max. horizontal speed & $15.2 \mathrm{~m} / \mathrm{s}$ \\
Max. vertical speed & $4 \mathrm{~m} / \mathrm{s}$ \\
Max. wind resistance & $13.9 \mathrm{~m} / \mathrm{s}$ \\
Max. transmission range & $4000 \mathrm{~m}$ \\
Max. altitude & $150 \mathrm{~m}$ \\
Operating temperature range & $-10 \mathrm{C}^{\circ}$ to $40 \mathrm{C}^{\circ}$ \\
Camera & $21 \mathrm{MP}$ \\
Resolution & $4608 \times 3456$ \\
Focal length & $4 \mathrm{~mm}$ \\
Pixel size & $1.34 \times 1.34 \mu \mathrm{m}$ \\
\hline
\end{tabular}

Pix4Dcapture, a cell phone application, has been used to prepare circular mission flight plan. The flight height was $30 \mathrm{~m}$ and GSD was $3.87 \mathrm{~cm} /$ pixel. Circular mission plan is used to take pictures of an object with 3D. In this study, 107 overlapping pictures were taken (Figure 4). The pictures were processed in Agisoft Metashape software 1.5.0. The steps is shown in Fig. 5.

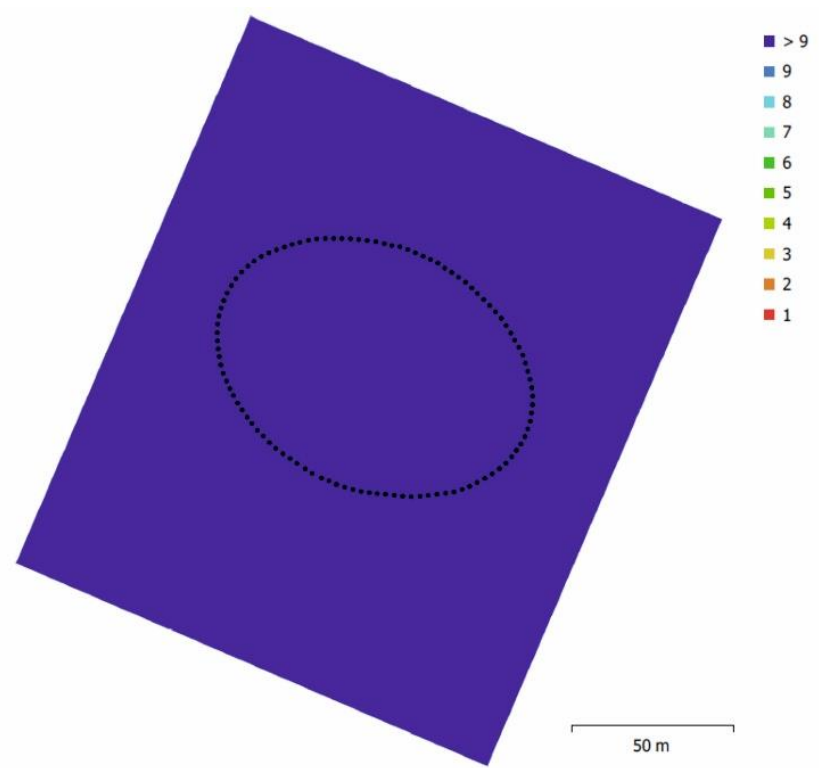

Figure 4. Camera locations 


\begin{tabular}{|c|}
\hline Add Photos \\
Convert coordinates of photos \\
Align Photos \\
Build mesh \\
Add ground control points \\
Input marker coordinates \\
Optimize camera \\
Build dense cloud \\
Build mesh \\
Build texture \\
Generate orthophoto \\
Generate DSM
\end{tabular}

Figure 5. Process steps

To georeference the study area, four ground control points were used. Coordinates were taken by using a GPS with one epoch. Error amounts are given in Table 2.

Table 2. Error amounts of ground control points

\begin{tabular}{ll}
\hline Direction & Error amount $(\mathrm{mm})$ \\
\hline X error & 6.19458 \\
Y error & 3.87626 \\
Z error & 4.81898 \\
XY error & 7.30741 \\
Total & 8.75333 \\
\hline
\end{tabular}

\section{Results}

In this study, 3D model was created with medium quality (Fig 6). High quality model needs high standards of computer. Moreover, pictures taken from close-range will increase the resolution of the model.

DSM (Fig. 7) and orthophoto (Fig. 8) of the study area were created. The elevation of the study area is between 906 and 928 meters. Orthophoto has too many white holes because of circular mission flight plan.

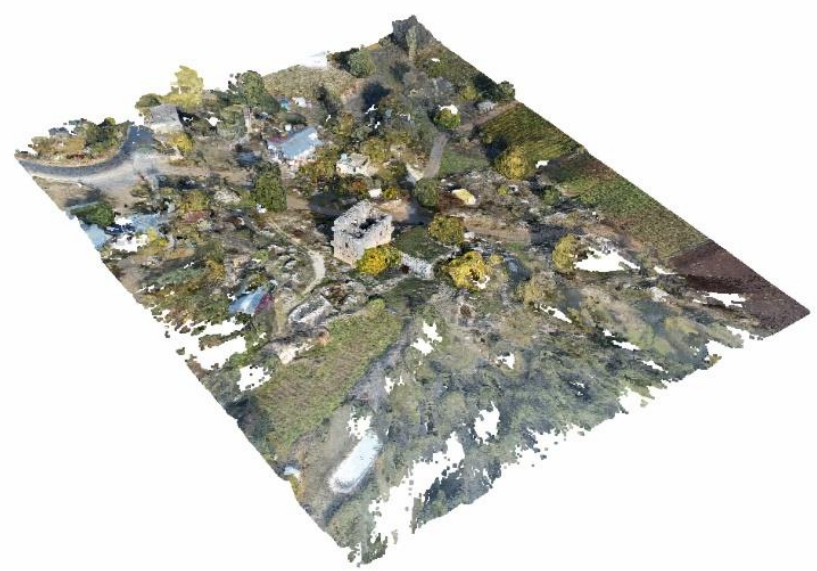

Figure 6. 3D Model

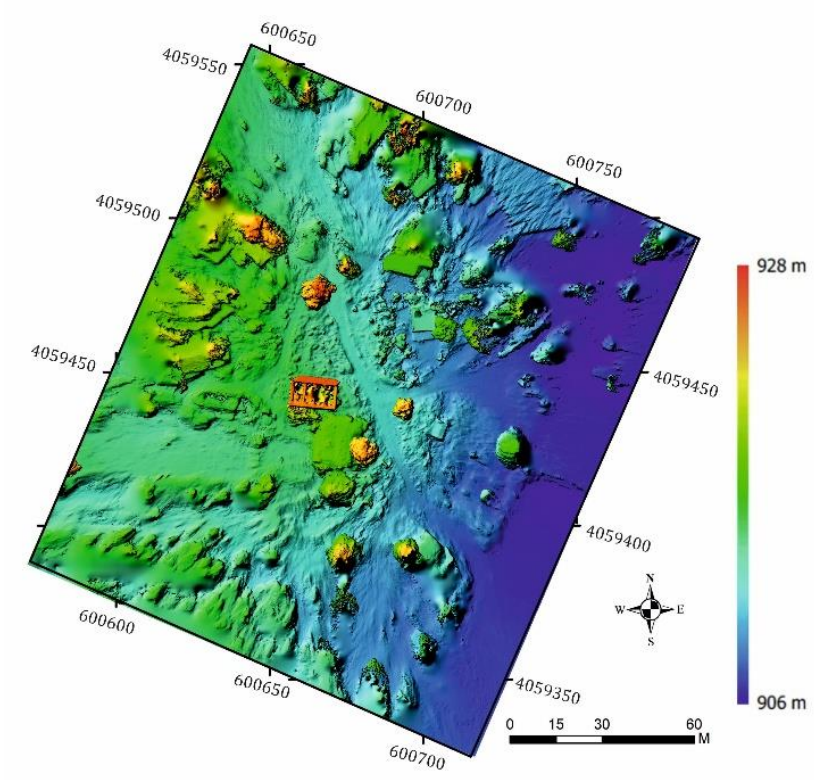

Figure 7. DSM

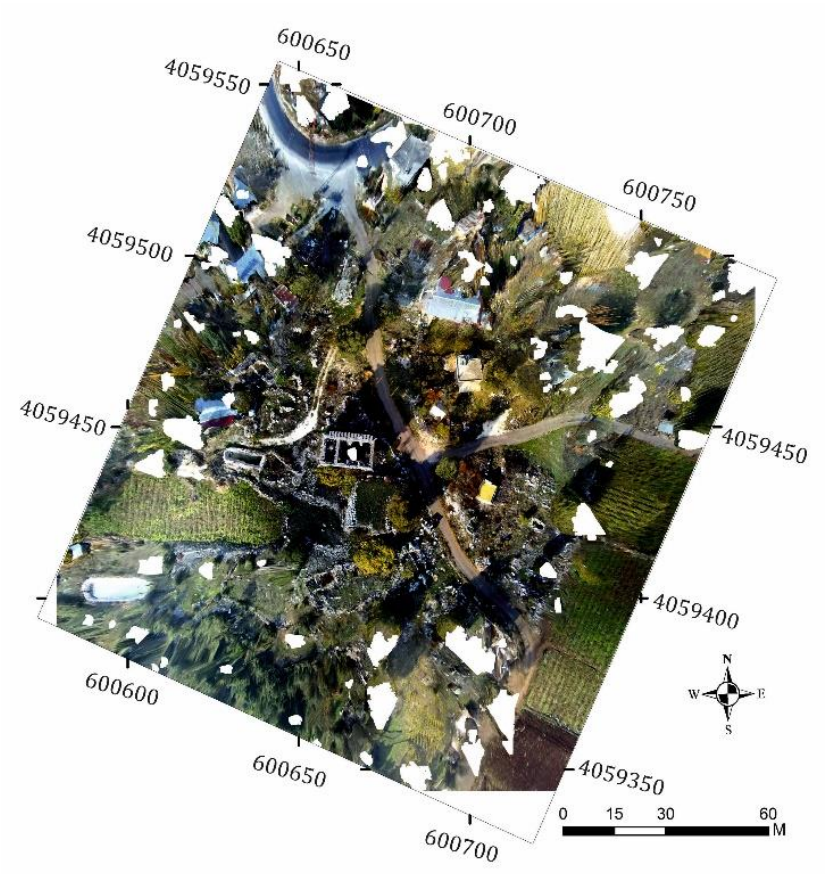

Figure 8. Orthophoto

\section{Discussion}

It is very important to transfer historical artifacts bearing the signatures of world history to future generations (Yakar et al. 2015). Along with the developing technology, the classical method of documentation has now been replaced by modern documentation techniques, which has led to the rapid advancement of contemporary documentation techniques (Korumaz et al. 2011).

In today, modelling of a cultural heritage is being performed with using a UAV. The pictures will be taken manually with a UAV. Overlapping pictures will be aligned with the help of tie points. The quality of the model will be increased when high quality aligned mode is selected.

Circular mission plan is an alternative to manually taken pictures. It will be used easily in Pix4Dcapture mobile application. 


\section{Conclusion}

Historical artifacts are in danger all over the world. Turkey has an ancient history. Too many civilizations have lived and left us precious cultural heritages. Documenting historical artifacts is vital to transfer cultural heritage to future generations. Modern technology allows us to create 3D model of the object with high accuracy in a short time. In this study, the model of Ucayak Ruins has been created in 3D. This model will be used in tourism advertisements.

\section{Author contributions}

Aydın Alptekin: Literature review, Field study, Modelling, Writing; Murat Yakar: Editing

\section{Conflicts of interest}

The authors declare no conflicts of interest.

\section{References}

Alptekin A \& Yakar M (2020). Determination of pond volume with using an unmanned aerial vehicle. Mersin Photogrammetry Journal, 2(2), 5963.

Alptekin A \& Yakar M (2021). İçel İli jeolojisine ve jeolojik sorunlarına genel bir bakış. İçel Dergisi, 1(1), 27-30.

Alptekin A, Çelik M Ö \& Yakar M (2019). Anıtmezarın yersel lazer tarayıcı kullanarak 3B modellenmesi. Türkiye Lidar Dergisi, 1(1), 1-4.

Al-Rawabdeh A, Moussa A, Foroutan M, El-Sheimy N \& Habib A (2017). Time series UAV image-based point clouds for landslide progression evaluation applications. Sensors, 17(10), 2378.

Bendig J, Bolten A, Bennertz S, Broscheit J, Eichfuss S \& Bareth G (2014). Estimating biomass of barley using crop surface models (CSMs) derived from UAV-based RGB imaging. Remote sensing, 6(11), 10395-10412.

Çalışkan M, Aydın A, Aydınoğlu Ü \& Kerem F (2009). Mersin: ören yerleri, kaleleri, müzeleri. İl Özel İdaresi.

Hamal S N G, Sarı B \& Ulvi A (2020). Using of Hybrid Data Acquisition Techniques for Cultural Heritage a Case Study of Pompeiopolis. Türkiye Insansiz Hava Araçları Dergisi, 2(2), 55-60.

Kabadayı A, Yunus K \& Yiğit A Y (2020). Comparison of documentation cultural artifacts using the 3D model in different software.Mersin Photogrammetry Journal, 2(2), 51-58.

Kocalar A C (2020). LATMOS GEOPARK (BEŞPARMAK MOUNTAINS) WITH HERAKLEIALATMOS ANTIQUE HARBOUR CITY AND BAFA LAKE NATURAL PARK IN TURKEY. Turkish Journal of Engineering, 4(4), 176-182.
Korumaz A G, Dülgerler O N \& Yakar M (2011). KÜLTÜREL MIRASIN BELGELENMESINDE DIJITTAL YAKLAȘIMLAR. Selçuk Üniversitesi Mühendislik, Bilim ve Teknoloji Dergisi, 26(3), 67-83.

Sarı B, Hamal S N G \& Ulvi A (2020). Documentation of complex structure using Unmanned Aerial Vehicle (UAV) photogrammetry method and Terrestrial Laser Scanner (TLS). Türkiye Lidar Dergisi, 2(2), 48- 54

Şasi A \& Yakar M (2018). Photogrammetric modelling of hasbey dar'ülhuffaz (masjid) using an unmanned aerial vehicle. International Journal of Engineering and Geosciences, 3(1), 6-11.

Şenol H İ, Yiğit A Y, Kaya Y \& Ulvi A (2021). İHA ve yersel fotogrametrik veri füzyonu ile kültürel mirasın 3 boyutlu (3B) modelleme uygulaması: Kanlıdivane Örneği. Türkiye Fotogrametri Dergisi, 3(1), 29-36.

Ulvi A \& Yakar M (2010). An experimental study on preparing photogrammetric rolove plans of antique theatres. International Journal of the Physical Sciences, 5(7), 1086-1092.

Ulvi A, Yakar M, Yiğit A \& Kaya Y (2019). The Use of Photogrammetric Techniques in Documenting Cultural Heritage: The Example of Aksaray Selime Sultan Tomb. Universal Journal of Engineering Science, 7(3), 64-73.

Ünel F B, Kuşak L, Çelik M Ö, Alptekin A \& Yakar M (2020). Kıyı Çizgisinin Belirlenerek Mülkiyet Durumunun İncelenmesi. Türkiye Arazi Yönetimi Dergisi, 2(1), 33-40.

Varol F, Yiğit A Y \& Ulvi A (2021). Kültürel Mirasın Dijital Ortamda 3 Boyutlu Arşivlenmesi: Maghoki-Attar Camii Sanal Model Örneği. Turizm Akademik Dergisi, 8 (1), 181-191.

Yakar M, Kabadayı A, Yiğit A Y, Çıkııcı K, Kaya Y \& Catin, S. S. (2016). Emir Saltuk Kümbeti Fotogrametrik Rölöve Çalişmasi ve 3Boyutlu Modellenmesi. Geomatik, 1(1), 14-18.

Yakar M, Orhan O, Ulvi A, Yiğit A Y \& Yüzer M M (2015). Sahip Ata Külliyesi Rölöve Örneği. TMMOB Harita ve Kadastro Mühendisleri Odası, 10.

Yakar M, Yıldız F \& Yılmaz H M (2005). Tarihi ve Kültürel Miraslarin Belgelenmesinde Jeodezi Fotogrametri Mühendislerinin Rolü. TMMOB Harita ve Kadastro Mühendisleri Odası, 10.

Yakar M, Yılmaz H M \& Mutluoğlu Ö (2010). Comparative evaluation of excavation volume by TLS and total topographic station based methods. Lasers in Eng,19, 331-345.

Yiğit A Y \& Uysal M (2021). Yüksek Çözünürlüklü İnsansız Hava Aracı (İHA) Görüntülerinden Karayolların Tespiti. Bitlis Eren Üniversitesi Fen Bilimleri Dergisi, 10 (3), 1040-1054. DOI: 10.17798/bitlisfen.900817

Yilmaz H M, Yakar M \& Yildiz F (2008). Digital photogrammetry in obtaining of 3D model data of irregular small objects. The International Archives of the Photogrammetry, Remote Sensing and Spatial Information Sciences, 37, 125-130. 